\section{Relative Susceptibility of New Apple Cultivars to Arthropod Pests}

\author{
Henry W. Hogmire ${ }^{1}$ \\ West Virginia University, Kearneysville Tree Fruit Research and Education \\ Center, P.O. Box 609, Kearneysville, WV 25430
}

\author{
Stephen S. Miller ${ }^{2}$ \\ U.S. Department of Agriculture, Agricultural Research Service, Appalachian \\ Fruit Research Station, 2217 Wiltshire Road, Kearneysville, WV 25430
}

Additional index words. Malus $\times$ domestica, cultivar evaluation, insect susceptibility

\begin{abstract}
As part of a regional NE-183 project (Multidisciplinary Evaluation of New Apple Cultivars), 23 apple (Malus $\times$ domestica Borkh.) cultivars were evaluated for arthropod pest susceptibility. Incidence or injury data were collected from six foliage and eight fruit pests under field conditions over a four year period (2000-03). Cultivars were ranked based on susceptibility (least to most) to each pest, and rankings were summed for members of the foliage and fruit pest group to develop a susceptibility rating for foliage, fruit and all pests combined. Cultivars with lowest susceptibility to foliage pests included 'GoldRush' and 'Pioneer Mac', whereas 'Yataka' and 'Cameo' were most susceptible. For fruit pests, susceptibility was lowest for 'Pristine' and 'Sunrise', and highest for 'Cameo', 'Fuji Red Sport \#2', and 'Gala Supreme'. When both foliage and fruit pests were combined, susceptibility was lowest for 'Sunrise' and 'Pioneer Mac', and highest for 'Cameo'. Some increasingly popular cultivars had high levels of injury from a few pests, including plum curculio and apple maggot on 'Ginger Gold', codling moth and oriental fruit moth on 'Cameo', and japanese beetle, plum curculio and apple maggot on 'Honeycrisp'. A positive and significant correlation was found between day of harvest and percent fruit injury from codling moth/oriental fruit moth and tufted apple bud moth/redbanded leafroller, with later maturing cultivars experiencing higher injury levels presumably due to more exposure to later generations of these pests. Differences among cultivars in pest incidence and injury can be used by growers to improve pest management through cultivar selection, or by making modifications in control programs based on cultivar susceptibility.
\end{abstract}

Eastern apple orchards are susceptible to injury from over 30 arthropod pests that attack the foliage, fruit, and woody parts of trees (Hogmire, 1995). To manage this pest complex and produce a marketable crop, growers have relied on 7 to 10 applications of crop protection chemicals (Pfeiffer, 1996) at an annual cost of \$200 to 300/acre (Krawczyk, 2004). Whereas the use of disease-resistant apple cultivars has provided an opportunity to reduce fungicide applications (Biggs etal., 2000), this management strategy has not been an option for arthropod pests due to a lack of commercially available cultivars with insect resistance.

Although information is more limited for insects than diseases, studies have been conducted that reveal differences in insect susceptibility among apple genotypes. Resistance of 'Northern Spy' to woolly apple aphid, Eriosoma lanigerum (Hausmann) is

Received for publication 19 May 2005. Accepted for publication 8 July 2005. Appreciation is extended to Kimberly Arbogast, Larry Crim, Elizabeth Fries, Natalie Harris, John Holliday, Samantha Hoover, Matthew Josleyn, Holly Lohman, Jessica Martin, Shelley Pearson, and Tim Winfield for technical assistance. Use of trade names does not imply endorsement of the products named, or criticism of similar ones not named.

${ }^{1}$ Professor of entomology; to whom reprint requests should be addressed; e-mail Henry.Hogmire@mail. wvu.edu.

${ }^{2}$ Research horticulturist. undoubtedly one of the earliest (Underhill and Cox, 1938) and most extensively (Cummins et al., 1981) studied examples of apple resistance to an arthropod pest. The crossing of 'Northern Spy' with Malling rootstock and some other resistant cultivars ('Ben Davis', 'Winter Majetin', and 'M793') resulted in the widely planted Malling-Merton (MM) series of roostocks that are resistant to woolly apple aphid (Bus, 1994; Crane, 1937; Cummins and Aldwinckle, 1974).

Studies have used various criteria to evaluarthropod pests, including pest incidence (Goonewardene et al., 1976), pest injury (Goonewardene et al., 1975, 1979; Dean and Chapman, 1973; Messina and Jones, 1990), effect on pest developmental time and survival (Mackenzie and Cummins, 1982), use of insect traps (Murphy et al., 1991; Rull and Prokopy, 2004), and video images of feeding damage (Chervin et al., 2000). Goonewardene et al. (1979) reported that 'Starking Delicious' was more resistant to damage by apple maggot, Rhagoletis pomonella (Walsh), than 'Jonathan' or 'Golden Delicious'; however, there was no difference in damage on these cultivars by plum curculio, Conotrachelus nenuphar (Herbst), and redbanded leafroller, Argyrotaenia velutinana Walker. Earlier ripening cultivars of apple were found to have higher levels of ovipositional injury from apple maggot (Dean and Chapman, 1973), ate the susceptibility of apple genotypes to which was believed to be due to a lower level of skin resistance to ovipositor penetration during peak apple maggot activity (Messina and Jones, 1990). However, Rull and Prokopy (2004) reported that apple maggot preference for apple genotypes appeared to be independent of fruit phenology, sugar content and pulp pressure. Some studies have been conducted to determine if there was any pest resistance among disease resistant cultivars. In a study of 33 disease-resistant selections, injury from codling moth, Cydia pomonella (Linnaeus), plum curculio, apple maggot, and redbanded leafroller was lower on $9.7 \%, 22.9 \%, 32.3 \%$, and $17.0 \%$ of the selections, respectively than on a 'Jonathan' check (Goonewardene et al., 1975). One selection with resistance to apple scab [Venturia inaequalis (Cke.) Wint.] was also found to have resistance to both plum curculio and european red mite, Panonychus ulmi (Koch) (Goonewardene, 1987). Other studies have also found differences in cultivar susceptibility to european red mite (Downing and Moilliet, 1967; Ghate and Howitt, 1965), and 'Delicious', 'Stayman', and 'Yorking' are recommended cultivars to sample for assessing population levels (Hogmire, 1995). Goonewardene et al. (1976) found that apple selections with more leaf hairs had higher levels of european red mites.

Although the above studies have contributed valuable information, evaluations were conducted with only a few cultivars and/or number of pests. Most were laboratory studies and/or based on 1 year of data. As part of a cooperative multi-state regional project(NE-183 Multidisciplinary Evaluation of New Apple Cultivars) (Greene et al., 2004), a planting of 23 apple cultivars was established in 1995 in 18 states, including West Virginia, and two Canadian provinces. The relative susceptibility of these cultivars to arthropod pests was reported for a single season in the New York planting (Straub, 2003). Our project provided an opportunity to assess the arthropod pest susceptibility of a large selection of apple cultivars under a range of West Virginia climatic conditions spanning multiple years. The objective of this study was to determine the susceptibility of these cultivars to a variety of foliage and fruit-feeding pests over 4 years.

\section{Materials and Methods}

Test planting. As part of a regional NE-183 project, a 0.14 -ha planting of 23 apple cultivars on Malling 9 (M.9) 337 rootstock was established in 1995 at the USDA-ARS Appalachian Fruit Research Station, Kearneysville, W.Va. Five single-tree replications of each cultivar were planted in north-south rows in a randomized block design at a spacing of $2.5 \times 4.3 \mathrm{~m}$. 'Golden Delicious' and 'Pioneer Mac' were included in this evaluation to provide standard commercial reference cultivars. Trees were trained to the central leader form and given minimal dormant pruning on an annual basis, primarily to contain the canopy to the allotted space and to enhance light penetration into the lower canopy. No pesticides were applied for insect and disease control in 1995. From 
1996 to 1999 , arthropod pests were managed with azinphosmethyl, carbaryl, chlorpyrifos, oil, methyl parathion, and phosmet applied at recommended rates (Pfeiffer, 1996). During this study, 2000 to 2003, applications were limited to oil (delayed dormant) and carbaryl (for fruit thinning), plus pyridaben in 2001. Disease control consisted of applications of fixed copper beginning in 1996, streptomycin beginning in 1998, and dodine, myclobutanil, fenarimol, and mancozeb in April and May of each year, beginning in 1999. Additional details regarding the planting and cultural maintenance of the orchard are provided by Crassweller et al. (2005).

Data collection and analysis. Incidence and injury from various foliage and fruit-feeding arthropod pests were assessed periodically throughout each of 4 years during 2000 to 2003. Incidence of rosy apple aphid, Dysaphis plantaginea (Passerini), was determined by counting the number of colonies on each tree during early to mid-June in 2000, 2001, and 2003. Populations of spirea aphid, Aphis spiraecola Patch, were evaluated by counting aphids on the most infested leaf on each of 10 terminals per tree during early to mid-June in 2000 and 2001. Incidence of white apple leafhopper, Typhlocyba pomaria McAtee, was determined by counting nymphs on the underside of 25 leaves per tree during early August or early September in 2000-02. Injury from spotted tentiform leafminer, Phyllonorycter blancardella (Fabr.), was evaluated by counting all tissue-feeder mines during a five-minute period per tree during early August or early September in 2000-02. Abundance of European red mite was determined by sampling 20 leaves per tree, removing mites with a mitebrushing machine, and counting motile stages with a binocular microscope during late June in 2000-01. Injury from japanese beetle, Popillia japonica Newman, was assessed by determining the number of injured leaves per tree during mid- to late July in 2000-02. Lack of incidence or injury data for some foliage pests in a given year was primarily due to low abundance. For each year, 2000-03, insect injury to fruit was determined by sampling and evaluating up to 100 picked apples and up to 100 drop apples per tree. Fruit were harvested for individual cultivars when the average starch index rating (rated on a 1 to 8 scale) fell within the range of 4 to 6 (considered optimum maturity for fresh consumption) based on the Cornell Generic Starch-Iodine Index Chart (Blanpied and Silsby, 1992). Internal worms were removed from injured fruit and species identified.

Data on incidence or injury from each arthropod pest was subjected to ANOVA, with means separation by Waller-Duncan $\mathrm{k}$ ratio $t$ test (SAS Institute 2001). Statistical analyses were conducted on 2 or 3 years of data for foliage pests and 4 years of data for fruit-feeding pests. Cultivars were numerically ranked from the least to the most susceptible to incidence or injury from each pest, and these rankings were summed to develop a pest susceptibility rating for foliage pests, fruit pests, and all pests combined. A correlation analysis was conducted to determine the relationship between day of year harvest date and fruit injury from codling moth, oriental fruit moth, tufted apple bud moth, and redbanded leafroller.

\section{Results and Discussion}

Mean incidence or injury was significantly different $(P=0.0001)$ among the 23 cultivars evaluated for each foliage pest (Table 1). Incidence of rosy apple aphid differed substantially among the cultivars, with a range of $<1$ to over 72 colonies/tree. 'GoldRush' and 'NY75414-1' were the least susceptible cultivars, with the highest infestation level occurring on 'Enterprise', a scab-resistant cultivar. Moderately low levels of $<20$ colonies/tree were found on 'Honeycrisp', 'Pioneer Mac', and 'Senshu', whereas higher levels of 40 to 50 colonies per tree occurred on 'Fortune', 'Fuji Red Sport \#2', 'Ginger Gold', 'Pristine', and 'Shizuka'. 'Golden Delicious', one of the standard cultivars in this study, was in the mid range of susceptibility with 34 colonies per tree. Incidence of rosy apple aphid was similar and low in 2000-01 (mean of two colonies per tree both years), but significantly higher in 2003 (mean of 91 colonies/tree) $(P=0.0001)$. Rosy apple aphid was the most problematic insect in many commercial orchards in 2003. Cool and wet spring conditions maintained foliage in a succulent condition for an extended time period, which was favorable for aphids but unfavorable for natural enemies. Cool weather also delayed aphid development, thus prolonging their time period on apple trees before migration to their summer host, buckhorn plantain (Plantago lanceolata L.) (Hogmire,

Table 1. Mean foliage pest incidence or injury on 23 appe cutivas gown at Kearneysville, W.Va., in the 1995 NE-183 Multidisciplinary Apple Cultivar Evaluation Regional project planting for the years 2000-03.

\begin{tabular}{|c|c|c|c|c|c|c|}
\hline Cultivar & $\begin{array}{c}\mathrm{RAA}^{\mathrm{z}} \\
\text { colonies/ } \\
\text { tree }\end{array}$ & $\begin{array}{c}\mathrm{SA} / \\
\text { most-infested } \\
\text { leaf/ } \\
\text { terminal }^{\mathrm{y}}\end{array}$ & $\begin{array}{c}\text { WALH } \\
\text { nymphs/ } \\
25 \text { leaves }\end{array}$ & $\begin{array}{l}\text { STLM } \\
\text { mines/ } \\
5 \text { min }^{x}\end{array}$ & $\begin{array}{c}\text { ERM/ } \\
\text { leaf }\end{array}$ & $\begin{array}{l}\text { JB injured } \\
\text { leaves/tree }\end{array}$ \\
\hline Arlet & $32.5 \mathrm{~b}-\mathrm{h}^{\mathrm{v}}$ & $1.2 \mathrm{abc}$ & $5.2 \mathrm{a}-\mathrm{g}$ & $20.2 \mathrm{~g}-\mathrm{j}$ & $103.4 \mathrm{a}$ & $1.9 \mathrm{~g}-\mathrm{j}$ \\
\hline Braeburn & $25.3 \mathrm{c}-\mathrm{h}$ & $0.6 \mathrm{e}-\mathrm{i}$ & $2.5 \mathrm{gh}$ & $22.1 \mathrm{e}-\mathrm{i}$ & $76.9 \mathrm{a}-\mathrm{d}$ & $2.1 \mathrm{~d}-\mathrm{h}$ \\
\hline Cameo & $33.3 \mathrm{~b}-\mathrm{h}$ & $1.1 \mathrm{a}-\mathrm{d}$ & $7.7 \mathrm{abc}$ & $43.9 \mathrm{a}$ & $79.7 \mathrm{a}-\mathrm{d}$ & $2.1 \mathrm{e}-\mathrm{i}$ \\
\hline Creston & $38.7 \mathrm{~b}-\mathrm{f}$ & $1.0 \mathrm{a}-\mathrm{e}$ & $4.8 \mathrm{c}-\mathrm{h}$ & $20.3 \mathrm{f}-\mathrm{j}$ & $85.3 \mathrm{abc}$ & $1.9 \mathrm{~g}-\mathrm{j}$ \\
\hline Enterprise & $72.2 \mathrm{a}$ & $1.2 \mathrm{ab}$ & $6.9 \mathrm{a}-\mathrm{d}$ & $19.9 \mathrm{hij}$ & $39.3 \mathrm{~d}$ & $3.4 \mathrm{a}$ \\
\hline Fortune & $43.2 \mathrm{bcd}$ & $0.9 \mathrm{a}-\mathrm{g}$ & $5.2 \mathrm{a}-\mathrm{g}$ & $37.8 \mathrm{ab}$ & $55.8 \mathrm{bcd}$ & $1.9 \mathrm{~g}-\mathrm{j}$ \\
\hline Fuji Red Sport \#2 & $50.5 \mathrm{ab}$ & $1.1 \mathrm{a}-\mathrm{d}$ & $5.6 \mathrm{a}-\mathrm{f}$ & $19.5 \mathrm{hij}$ & $72.6 \mathrm{a}-\mathrm{d}$ & $2.5 \mathrm{~b}-\mathrm{f}$ \\
\hline Gala Supreme & $22.9 \mathrm{~d}-\mathrm{i}$ & $0.9 \mathrm{a}-\mathrm{g}$ & $3.8 \mathrm{e}-\mathrm{h}$ & $23.1 \mathrm{e}-\mathrm{i}$ & $75.3 \mathrm{a}-\mathrm{d}$ & $2.8 \mathrm{~b}$ \\
\hline Ginger Gold & $44.6 \mathrm{bc}$ & $0.6 \mathrm{e}-\mathrm{j}$ & $4.6 \mathrm{~d}-\mathrm{h}$ & $24.2 \mathrm{~d}-\mathrm{i}$ & $70.2 \mathrm{a}-\mathrm{d}$ & $2.7 \mathrm{bc}$ \\
\hline Golden Delicious & $34.0 \mathrm{~b}-\mathrm{h}$ & $0.8 \mathrm{~b}-\mathrm{g}$ & $2.5 \mathrm{gh}$ & $18.5 \mathrm{hij}$ & $87.6 a b c$ & $2.1 \mathrm{e}-\mathrm{i}$ \\
\hline Golden Supreme & $24.5 \mathrm{c}-\mathrm{h}$ & $0.7 \mathrm{c}-\mathrm{h}$ & $8.0 \mathrm{ab}$ & $36.3 \mathrm{abc}$ & $89.5 \mathrm{abc}$ & $1.3 \mathrm{~lm}$ \\
\hline GoldRush & $0.4 \mathrm{j}$ & $0.1 \mathrm{j}$ & $4.4 \mathrm{~d}-\mathrm{h}$ & $24.5 \mathrm{~d}-\mathrm{i}$ & $54.6 \mathrm{~cd}$ & $1.1 \mathrm{~m}$ \\
\hline Honeycrisp & $18.9 \mathrm{f}-\mathrm{j}$ & $0.1 \mathrm{ij}$ & $5.2 \mathrm{a}-\mathrm{g}$ & $16.9 \mathrm{ij}$ & $87.7 \mathrm{abc}$ & $3.5 \mathrm{a}$ \\
\hline NY75414-1 & $1.8 \mathrm{ij}$ & $0.5 \mathrm{~g}-\mathrm{j}$ & $8.1 \mathrm{a}$ & $30.3 \mathrm{~b}-\mathrm{f}$ & $81.0 \mathrm{a}-\mathrm{d}$ & $2.8 \mathrm{~b}$ \\
\hline Orin & $35.7 \mathrm{~b}-\mathrm{h}$ & $0.5 \mathrm{f}-\mathrm{j}$ & $4.6 \mathrm{~d}-\mathrm{h}$ & $27.9 \mathrm{~b}-\mathrm{h}$ & $86.5 \mathrm{abc}$ & $2.6 \mathrm{bcd}$ \\
\hline Pioneer Mac & $14.5 \mathrm{hij}$ & $0.6 \mathrm{e}-\mathrm{h}$ & $1.9 \mathrm{~h}$ & $25.3 \mathrm{~d}-\mathrm{i}$ & $40.4 \mathrm{~d}$ & $1.6 \mathrm{i}-1$ \\
\hline Pristine & $40.8 \mathrm{~b}-\mathrm{e}$ & $0.7 \mathrm{~d}-\mathrm{h}$ & $6.0 \mathrm{a}-\mathrm{e}$ & $27.0 \mathrm{c}-\mathrm{h}$ & $104.7 \mathrm{a}$ & $2.3 \mathrm{c}-\mathrm{g}$ \\
\hline Sansa & $27.5 \mathrm{c}-\mathrm{h}$ & $0.9 \mathrm{a}-\mathrm{g}$ & $4.5 \mathrm{~d}-\mathrm{h}$ & $16.3 \mathrm{ij}$ & $74.3 \mathrm{a}-\mathrm{d}$ & $1.7 \mathrm{~h}-\mathrm{k}$ \\
\hline Senshu & $19.7 \mathrm{e}-\mathrm{j}$ & $1.2 \mathrm{ab}$ & $7.3 \mathrm{a}-\mathrm{d}$ & $23.5 \mathrm{e}-\mathrm{i}$ & $67.4 \mathrm{a}-\mathrm{d}$ & $2.5 \mathrm{~b}-\mathrm{e}$ \\
\hline Shizuka & $40.7 \mathrm{~b}-\mathrm{e}$ & $1.3 \mathrm{a}$ & $2.8 \mathrm{fgh}$ & $33.5 \mathrm{bcd}$ & $98.8 \mathrm{ab}$ & $1.8 \mathrm{~g}-\mathrm{j}$ \\
\hline Suncrisp & $36.7 \mathrm{~b}-\mathrm{g}$ & $0.7 \mathrm{c}-\mathrm{h}$ & $4.6 \mathrm{~d}-\mathrm{h}$ & $25.1 \mathrm{~d}-\mathrm{i}$ & $57.0 \mathrm{bcd}$ & $1.5 \mathrm{jkl}$ \\
\hline Sunrise & $31.0 \mathrm{~b}-\mathrm{h}$ & $1.0 \mathrm{a}-\mathrm{f}$ & $3.3 \mathrm{e}-\mathrm{h}$ & $30.3 \mathrm{~b}-\mathrm{g}$ & $67.9 \mathrm{a}-\mathrm{d}$ & $1.5 \mathrm{klm}$ \\
\hline Yataka & $39.7 \mathrm{~b}-\mathrm{f}$ & $1.1 \mathrm{a}-\mathrm{d}$ & $3.4 \mathrm{e}-\mathrm{h}$ & $31.9 \mathrm{~b}-\mathrm{e}$ & $104.3 \mathrm{a}$ & $2.5 \mathrm{~b}-\mathrm{f}$ \\
\hline
\end{tabular}

${ }^{2} \mathrm{RAA}=$ rosy apple aphid; SA $=$ spirea aphid; $\mathrm{WALH}=$ white apple leafhopper; STLM $=$ spotted tentiform leafminer; ERM = european red mite; JB = japanese beetle.

${ }^{y}$ Rating for SA/most infested leaf/terminal: $0=$ none, $1=1$ to $20,2=21$ to $100,3=101$ to 200 , and $4=>200$. ${ }^{\mathrm{x}}$ Mines counted per five minutes of canopy inspection time.

"Rating for JB injured leaves/tree: $0=$ none, $1=1$ to $50,2=51$ to $100,3=101$ to $200,4=>200$.

${ }^{\vee}$ Different letters denote significant differences among means according to the Waller-Duncan test $(P \leq 0.05)$. 
Table 2. Mean fruit injury at harvest from various arthropod pests on 23 apple cultivars grown at Kearneysville, W.Va., in the1995 NE-183 Multidisciplinary Apple Cultivar Evaluation Regional project planting for 2000-03.

\begin{tabular}{|c|c|c|c|c|c|c|c|}
\hline \multirow[b]{2}{*}{ Cultivar } & \multicolumn{6}{|c|}{ Percent fruit injury by } & \multirow{2}{*}{$\begin{array}{l}\text { Percent } \\
\text { clean fruit }\end{array}$} \\
\hline & $\mathrm{TPB}^{\mathrm{z}}$ & $\mathrm{PC}$ & $\mathrm{CM}$ and OFM & TABM and RBLR & AM & EAS & \\
\hline Arlet & $2.9 \mathrm{e}^{\mathrm{y}}$ & $7.9 \mathrm{a}-\mathrm{d}$ & $8.9 \mathrm{~lm}$ & 5.9 hij & $39.9 \mathrm{ab}$ & $0.5 \mathrm{ef}$ & $43.4 \mathrm{f}-\mathrm{i}$ \\
\hline Braeburn & $1.4 \mathrm{e}$ & $3.9 \mathrm{~d}$ & $24.3 \mathrm{e}-\mathrm{i}$ & $17.0 \mathrm{bc}$ & $27.7 \mathrm{bcd}$ & $2.2 \mathrm{bcd}$ & $35.3 \mathrm{~h}-\mathrm{k}$ \\
\hline Cameo & $6.6 \mathrm{a}-\mathrm{d}$ & $9.1 \mathrm{a}-\mathrm{d}$ & $37.0 \mathrm{a}$ & $12.7 \mathrm{cde}$ & $13.6 \mathrm{~g}-\mathrm{j}$ & $2.1 \mathrm{~b}-\mathrm{e}$ & $32.2 \mathrm{jk}$ \\
\hline Creston & $3.5 \mathrm{de}$ & $8.5 \mathrm{a}-\mathrm{d}$ & $28.1 \mathrm{c}-\mathrm{h}$ & $8.4 \mathrm{e}-\mathrm{i}$ & $15.2 \mathrm{f}-\mathrm{j}$ & $1.5 \mathrm{~b}-\mathrm{f}$ & $41.2 \mathrm{f}-\mathrm{j}$ \\
\hline Enterprise & $2.7 \mathrm{e}$ & $10.0 \mathrm{a}-\mathrm{d}$ & $21.3 \mathrm{~h}-\mathrm{j}$ & $16.7 \mathrm{bc}$ & $16.2 \mathrm{f}-\mathrm{i}$ & $1.6 \mathrm{~b}-\mathrm{f}$ & $42.4 \mathrm{f}-\mathrm{i}$ \\
\hline Fortune & $2.8 \mathrm{e}$ & $6.3 \mathrm{~cd}$ & $30.0 \mathrm{~b}-\mathrm{f}$ & $14.6 \mathrm{~cd}$ & $25.3 \mathrm{c}-\mathrm{f}$ & 0.7 def & $40.9 \mathrm{f}-\mathrm{k}$ \\
\hline Fuji Red Sport \#2 & 3.9 cde & $4.5 \mathrm{~d}$ & $25.6 \mathrm{~d}-\mathrm{h}$ & $17.0 \mathrm{bc}$ & $18.6 \mathrm{e}-\mathrm{h}$ & $2.3 \mathrm{bc}$ & $42.8 \mathrm{f}-\mathrm{i}$ \\
\hline Gala Supreme & $4.3 \mathrm{~b}-\mathrm{e}$ & $6.9 \mathrm{bcd}$ & $35.9 \mathrm{ab}$ & $26.5 \mathrm{a}$ & $8.8 \mathrm{~h}-1$ & $1.9 \mathrm{~b}-\mathrm{e}$ & $31.1 \mathrm{k}$ \\
\hline Ginger Gold & $4.2 \mathrm{~b}-\mathrm{e}$ & $14.0 \mathrm{ab}$ & $6.3 \mathrm{~lm}$ & $6.8 \mathrm{~g}-\mathrm{j}$ & $47.1 \mathrm{a}$ & $0.0 \mathrm{f}$ & $37.9 \mathrm{~g}-\mathrm{k}$ \\
\hline Golden Delicious & 3.7 cde & $7.9 \mathrm{a}-\mathrm{d}$ & $33.1 \mathrm{abc}$ & 6.0 hij & $12.9 \mathrm{~g}-\mathrm{j}$ & $0.8 \mathrm{c}-\mathrm{f}$ & $44.3 \mathrm{e}-\mathrm{h}$ \\
\hline Golden Supreme & $8.1 \mathrm{a}$ & $12.6 \mathrm{abc}$ & $17.6 \mathrm{ijk}$ & $5.3 \mathrm{ij}$ & $11.0 \mathrm{~h}-\mathrm{k}$ & $4.9 \mathrm{a}$ & $56.7 \mathrm{bcd}$ \\
\hline GoldRush & $4.1 \mathrm{cde}$ & $4.5 \mathrm{~d}$ & $37.9 \mathrm{a}$ & $20.3 \mathrm{~b}$ & $0.8 \mathrm{kl}$ & $0.9 \mathrm{c}-\mathrm{f}$ & $45.0 \mathrm{e}-\mathrm{h}$ \\
\hline Honeycrisp & 3.9 cde & $14.6 \mathrm{a}$ & $13.0 \mathrm{kl}$ & $4.6 \mathrm{ij}$ & $33.4 \mathrm{bcd}$ & $3.0 \mathrm{~b}$ & $43.0 \mathrm{f}-\mathrm{i}$ \\
\hline NY75414-1 & $1.3 \mathrm{e}$ & $9.7 \mathrm{a}-\mathrm{d}$ & $23.1 \mathrm{~g}-\mathrm{j}$ & $7.1 \mathrm{f}-\mathrm{j}$ & $2.0 \mathrm{kl}$ & $1.0 \mathrm{c}-\mathrm{f}$ & $59.7 \mathrm{~b}$ \\
\hline Orin & $2.2 \mathrm{e}$ & $9.5 \mathrm{a}-\mathrm{d}$ & $23.8 \mathrm{f}-\mathrm{j}$ & $12.7 \mathrm{cde}$ & $14.3 \mathrm{~g}-\mathrm{j}$ & $0.8 \mathrm{c}-\mathrm{f}$ & $49.4 \mathrm{c}-\mathrm{f}$ \\
\hline Pioneer Mac & $1.6 \mathrm{e}$ & $12.7 \mathrm{abc}$ & $17.0 \mathrm{jk}$ & $5.4 \mathrm{ij}$ & $13.7 \mathrm{~g}-\mathrm{j}$ & $0.9 \mathrm{c}-\mathrm{f}$ & $53.5 \mathrm{~b}-\mathrm{e}$ \\
\hline Pristine & $3.3 \mathrm{de}$ & $8.1 \mathrm{a}-\mathrm{d}$ & $2.8 \mathrm{~m}$ & $6.5 \mathrm{~g}-\mathrm{j}$ & 0.01 & $0.0 \mathrm{f}$ & $80.3 \mathrm{a}$ \\
\hline Sansa & $2.7 \mathrm{e}$ & $8.8 \mathrm{a}-\mathrm{d}$ & $7.3 \mathrm{~lm}$ & $7.1 \mathrm{f}-\mathrm{j}$ & $35.1 \mathrm{bc}$ & $1.0 \mathrm{c}-\mathrm{f}$ & $47.8 \mathrm{~d}-\mathrm{g}$ \\
\hline Senshu & $2.6 \mathrm{e}$ & $6.0 \mathrm{~cd}$ & $29.9 \mathrm{~b}-\mathrm{g}$ & $6.7 \mathrm{~g}-\mathrm{j}$ & $4.8 \mathrm{jkl}$ & $0.1 \mathrm{f}$ & $53.7 \mathrm{~b}-\mathrm{e}$ \\
\hline Shizuka & 3.7 cde & $5.6 \mathrm{~cd}$ & $23.8 \mathrm{f}-\mathrm{j}$ & $10.2 \mathrm{~d}-\mathrm{h}$ & $35.0 \mathrm{bc}$ & $1.5 \mathrm{~b}-\mathrm{f}$ & $33.5 \mathrm{ijk}$ \\
\hline Suncrisp & $7.7 \mathrm{ab}$ & $3.5 \mathrm{~d}$ & $31.1 \mathrm{a}-\mathrm{e}$ & $11.7 \mathrm{def}$ & $15.9 \mathrm{f}-\mathrm{i}$ & $2.7 \mathrm{~b}$ & $41.4 \mathrm{f}-\mathrm{j}$ \\
\hline Sunrise & $4.8 \mathrm{a}-\mathrm{e}$ & $8.0 \mathrm{a}-\mathrm{d}$ & $2.4 \mathrm{~m}$ & $3.1 \mathrm{j}$ & $23.6 \mathrm{~d}-\mathrm{g}$ & 0.7 def & $59.1 \mathrm{bc}$ \\
\hline Yataka & $1.8 \mathrm{e}$ & $9.7 \mathrm{a}-\mathrm{d}$ & $21.3 \mathrm{~h}-\mathrm{j}$ & $4.5 \mathrm{ij}$ & $16.5 \mathrm{f}-\mathrm{i}$ & $2.7 \mathrm{~b}$ & $54.2 \mathrm{~b}-\mathrm{e}$ \\
\hline
\end{tabular}

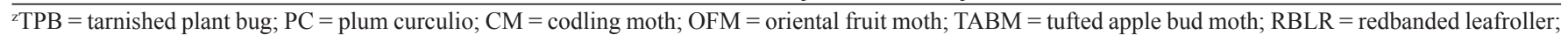
$\mathrm{AM}=$ apple maggot; $\mathrm{EAS}=$ european apple sawfly.

${ }^{y}$ Different letters denote significant differences among means according to the Waller-Duncan test $(P \leq 0.05)$.

most susceptible cultivars; however, mite populations on all cultivars were $<2 /$ leaf. The mite population in our study was significantly higher $(P=0.0001)$ in 2001 than in 2000 , with a mean of 145.7 and 7.4 mites/leaf, respectively. During 2000, in which the population range among the 23 cultivars was 1.9 to 33.2 /leaf, 'Ginger Gold' and 'Braeburn' had the second and third highest mite levels with 13.9 and 13.6/leaf, respectively. When both years were averaged, these two cultivars were also similar, but moderate in susceptibility with 76.9 and 70.2 mites/leaf, respectively. Reasons for the large difference in the mite population between 2000 and 2001 are not clear. Rainfall before mite counting was similar in both years, and the average spring temperature in 2001 was three degrees cooler than in 2000, which should have resulted in a lower rather than higher population. Oil and carbaryl were applied at the same rate and at approximately the same time each year. It's possible that significant freeze events at $1 / 2$-inch green and at bloom in 2000 (Hogmire et al., 2000) could have caused some mite mortality, resulting in a lower population as compared with 2001. The rating for japanese beetle injury ranged from 1.1 to 3.5 . Least susceptible cultivars (rating $\leq 1.5$ ) included 'Golden Supreme', 'GoldRush', 'Suncrisp', and 'Sunrise', whereas the most susceptible cultivars (rating >3) included 'Enterprise' and 'Honeycrisp'. Foliage injury, in terms of the amount of leaf tissue consumed per leaf and overall visual appearance, was especially severe on 'Honeycrisp'.

Percent fruit injury from each of the insects evaluated, as well as the percent clean fruit, was significantly different among the 23 cultivars $(P$ $=0.0001)$ (Table 2). Injury from tarnished plant bug, Lygus lineolaris (Palisot de Deauvois), ranged from $1.3 \%$ to $8.1 \%$. Cultivars with $<2 \%$ injury included 'Braeburn', 'NY75414-1', 'Pio- neer Mac', and 'Yataka', whereas the highest injury ( $>6 \%$ ) occurred on 'Cameo', 'Golden Supreme', and 'Suncrisp'. 'Golden Delicious' exhibited moderate susceptibility with $3.7 \%$ injury. Injury from plum curculio was higher, ranging from $3.5 \%$ to $14.6 \%$. The lowest levels of injury $(<5 \%)$ were found on 'Braeburn', 'Fuji Red Sport \#2', 'GoldRush', and 'Suncrisp', whereas injury was highest $(>12 \%)$ on 'Ginger Gold', 'Golden Supreme', 'Honeycrisp', and 'Pioneer Mac'. Injury on 'Golden Delicious' was again moderate at 7.9\%. In the New York study, where injury was higher $(0.2 \%$ to $31.5 \%)$, $38 \%$ of the cultivars had $<5 \%$ injury (Straub, 2003). Least susceptible cultivars were 'Arlet' and 'Enterprise', and most susceptible were 'Cameo', 'Yataka', and 'Suncrisp'.

There was a wide range in cultivar susceptibility to codling moth and oriental fruit moth, Grapholita molesta (Busck), with injury ranging from $2.4 \%$ to $37.9 \%$. The lowest injury $(<3 \%)$ occurred on 'Pristine' and 'Sunrise', whereas the highest injury $(>30 \%)$ was found on 'Golden Delicious', 'Cameo', 'Gala Supreme', 'GoldRush', and 'Suncrisp'. Nine cultivars had $20 \%$ to $30 \%$ injury. Whereas both insect species were responsible for the injury, the internal worms identified from harvested fruit were primarily codling moth $(87 \%)$. Although codling moth injury in the New York study was slightly lower $(0.2 \%$ to $20.9 \%$ ), 'Pristine' and 'Sunrise' were also the least susceptible cultivars, and 'GoldRush' and 'Gala Supreme' also ranked high in susceptibility (Straub, 2003). Injury from two leafroller species, tufted apple bud moth, Platynota idaeusalis (Walker), and redbanded leafroller ranged from $3.1 \%$ to $26.5 \%$. The lowest injury $(<5 \%)$ occurred on 'Honeycrisp', 'Sunrise', and 'Yataka', with the highest injury ( $>20 \%)$ found on 'Gala Supreme' and 'GoldRush'. Eight cultivars had $10 \%$ to $20 \%$ injury, whereas
'Golden Delicious' was low in susceptibility with only $6 \%$ injury. The greatest difference in cultivar susceptibility occurred with apple maggot, with injury ranging from $0 \%$ to $47.1 \%$. The lowest injury ( $\leq 2 \%)$ occurred on 'GoldRush', 'NY75414-1', and 'Pristine', whereas the highest injury ( $\geq 35 \%$ ) was found on 'Arlet', 'Ginger Gold', 'Sansa', and 'Shizuka'. Thirteen cultivars had $10 \%$ to $30 \%$ injury, with 'Golden Delicious' of moderate susceptibility with $12.9 \%$ injury. Under conditions of much higher injury in New York (11.5\% to $99.3 \%$ ), three of the least susceptible four cultivars were also 'NY75414-1', 'GoldRush', and 'Pristine', with 'Arlet' being the most susceptible cultivar (Straub, 2003). For apple maggot injury to occur, fruit must be attractive for oviposition at the period of adult activity during July and August. 'Pristine', which was free of apple maggot injury, would have escaped a majority of the oviposition period because of its midJuly harvest. On the other hand, the low level of injury on 'GoldRush', which was harvested in late October, may have been due to the unattractiveness (immaturity) of this cultivar during the oviposition period (Dean and Chapman, 1973). The level of injury from European apple sawfly, Hoplocampa testudinea (Klug), was quite low on all cultivars, ranging from $0 \%$ to $4.9 \%$. The lowest injury $(<0.5 \%)$ occurred on 'Ginger Gold', 'Pristine', and 'Senshu', with the highest injury ( $\geq 3 \%$ ) on 'Golden Supreme' and 'Honeycrisp'. Of the 23 cultivars, 'Pristine' had the highest percent of clean fruit (80.3\%), primarily due to the fact that it was not exposed to most of the apple maggot oviposition period, and to late generations of internal Lepidoptera and leafrollers because of its mid-July harvest. Clean fruit was $>50 \%$ for 'Golden Supreme', 'NY75414-1', 'Senshu', 'Sunrise', 'Pioneer Mac', and 'Yataka', but $<35 \%$ for 'Cameo' and 'Gala Supreme'. 


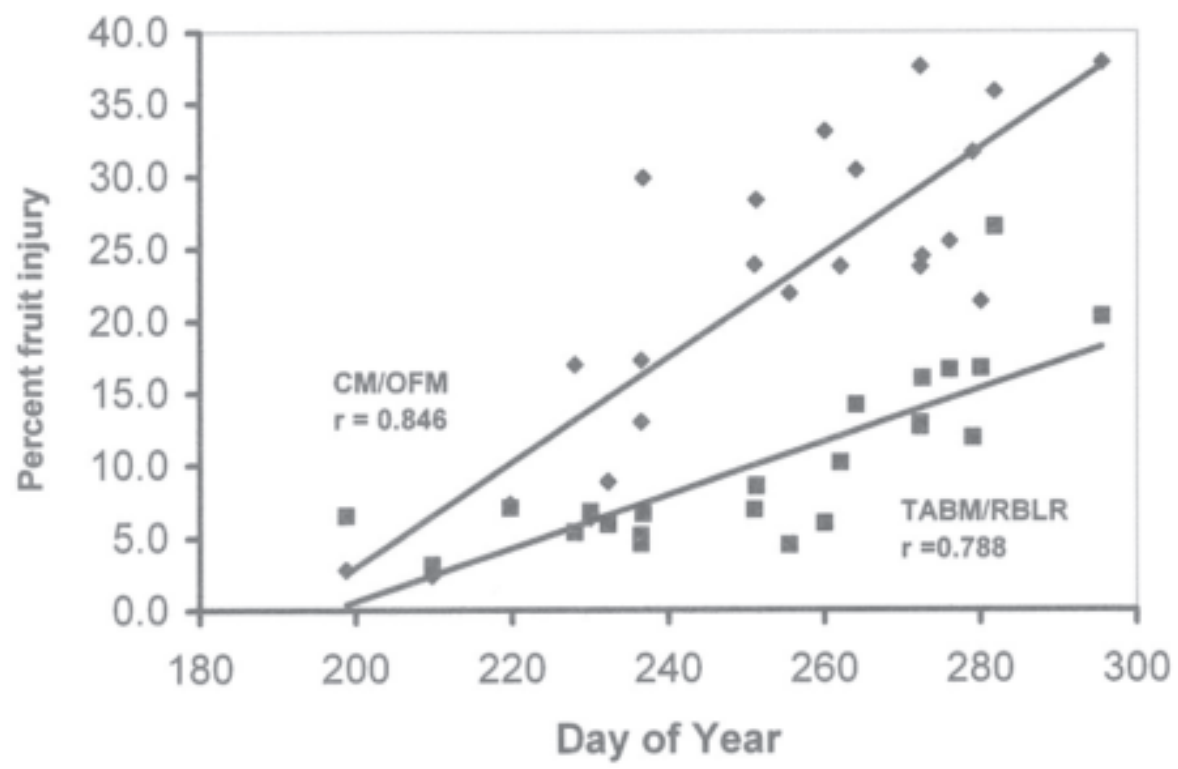

Fig. 1. Correlation between day of the year harvest date and percent fruit injury for codling moth/oriental fruit moth $(\mathrm{CM} / \mathrm{OFM}, \boldsymbol{)})$ and tufted apple bud moth/redbanded leafroller (TABM/RBLR, $\mathbf{\square})(p=$ 0.0001 ) among 23 apple cultivars in the NE-183 Regional Project planting at Kearneysville, W.Va. averaged over four growing seasons (2000-03).

There was a positive and significant correlation between average percent fruit injury and day of harvest (Crassweller et al., 2005) for the four year study for both codling moth/oriental fruit moth $(r=0.846, P=0.0001)$ and tufted apple bud moth/redbanded leafroller $(r=0.788$, $P=0.0001)$ (Fig. 1). Fruit are exposed to injury throughout much of the growing season from two generations of tufted apple bud moth, three generations of codling moth and redbanded leafroller, and up to five generations of oriental fruit moth in the mid-Atlantic region(Hogmire, 1995). Late maturing cultivars, such as 'Gala Supreme' and 'GoldRush' [that matured 18 and $26 \mathrm{~d}$ respectively after 'Golden Delicious' (Miller et al., 2004)] would be exposed to all generations of these insects, resulting in increased opportunity for fruit injury. In contrast, 'Pristine' and 'Sunrise' that were harvested in late July to early Aug. [58 and $47 \mathrm{~d}$ respectively before 'Golden Delicious' (Miller et al., 2004)] would not be exposed to the later generations, and therefore could be managed with fewer insecticides. For apple maggot, which has a single generation and causes injury to fruit over a much shorter time period (July to August), the correlation between average percent fruitinjury and day of harvest was weak and not significant ( $r=0.189, P=0.3881)$. Correlations would not be expected for the other fruit-feeding insects (tarnished plant bug, plum curculio, european apple sawfly), since they cause injury early in the season before any cultivars would be harvested.

This study demonstrates that closely related cultivars can differ substantially in insect susceptibility. Although 'Fuji Red Sport \#2' and 'Yataka', its bud mutation (Greene et al., 1997) were similar in overall susceptibility to foliage pests (rating of 41 vs. 45, Table 3), 'Fuji Red Sport \#2' was much more susceptible to fruit-feeding pests than 'Yataka' (rating of 69 vs. 47, Table 3). This difference in susceppests combined (Table 3). For foliage pests,

Cultivars were ranked numerically (from least to most susceptible) for each pest, and rankings were summed to develop a pest the least susceptible cultivars were 'GoldRush' and 'Pioneer Mac', and the most susceptible were 'Yataka', 'Cameo', and 'Enterprise'. Pest susceptibility to all fruit pests combined was lowest for 'Pristine' and 'Sunrise', and highest for 'Cameo', 'Fuji Red Sport \#2', and 'Gala Supreme'. When both foliage and fruit pests were combined, susceptibility was lowest for 'Sunrise' and 'Pioneer Mac', and highest for 'Cameo'.

In conclusion, we found significant differences among 23 cultivars in susceptibility to all six foliage and eight fruit pests that were studied. Some pests caused high levels of injury on a few cultivars of increasing popularity, such as plum curculio and apple maggot on 'Ginger Gold', codling moth and oriental fruit moth on 'Cameo', and japanese beetle, plum curculio and apple maggot on 'Honeycrisp'. 'Enterprise', a scab-resistant cultivar, was highly susceptible to rosy apple aphid and japanese beetle. Late maturing cultivars, such as 'Gala Supreme' and 'GoldRush', had higher levels of injury from codling moth, oriental fruit moth, and leafrollers because of greater exposure to later generations of these pests than early maturing cultivars. Based on their low susceptibility rating to all arthropod pests combined, cultivars worthy of consideration include 'Sunrise' and 'Pioneer Mac'. This knowledge can be used by growers to improve pest management through cultivar selection, or by making modifications in management programs based on cultivar susceptibility.

\section{Literature Cited}

Biggs, A.R., H.W. Hogmire, and A.R. Collins. 2000 Assessment of an alternative IPM program for the production of apples for processing. Plant Dis. 84:1140-1146.

Blanpied, G.D. and K.J. Silsby. 1992. Predicting harvest date windows for apples. Cornell Coop.
Table 3. Mean susceptibility rating among 23 apple cultivars to foliage and fruit pests in the $1995 \mathrm{NE}-$ 183 Multidisciplinary Apple Cultivar Evaluation Regional project planting at Kearneysville, W.Va., in 2000-03.

\begin{tabular}{lccc}
\hline & & Pest susceptibility rating & \\
\cline { 2 - 4 } Cultivar & Foliage pests & Fruit pests & All pests \\
\hline Arlet & $40^{2, y}$ & 49 & 89 \\
Braeburn & 33 & 60 & 93 \\
Cameo & 44 & 74 & 118 \\
Creston & 35 & 62 & 97 \\
Enterprise & 43 & 64 & 107 \\
Fortune & 35 & 63 & 98 \\
Fuji Red Sport $\# 2$ & 41 & 69 & 110 \\
Gala Supreme & 36 & 68 & 104 \\
Ginger Gold & 39 & 60 & 99 \\
Golden Delicious & 27 & 55 & 82 \\
Golden Supreme & 38 & 54 & 92 \\
GoldRush & 18 & 61 & 79 \\
Honeycrisp & 29 & 55 & 84 \\
NY75414-1 & 35 & 47 & 82 \\
Orin & 40 & 61 & 101 \\
Pioneer Mac & 21 & 47 & 68 \\
Pristine & 43 & 33 & 76 \\
Sansa & 30 & 53 & 83 \\
Senshu & 35 & 47 & 82 \\
Shizuka & 42 & 64 & 106 \\
Suncrisp & 30 & 66 & 96 \\
Sunrise & 30 & 45 & 65 \\
Yataka & 45 & & 92
\end{tabular}

${ }^{2}$ Lower rating indicates lower susceptibility.

${ }^{y}$ Rating is the summation of rankings for susceptibility to all arthropod pests within each group (column). 
Ext. Publ. Info. Bul. 221.

Bus, V. 1994. Pest and disease resistance in pipfruit rootstocks. Orchardist N.Z. 67(9):57-58.

Chervin, C., P. Franz, S. Kulkarni, S. Whitmore, and G. McGregor.2000.Amethod to screen pome fruit for resistance to skin-chewing insects and to analyze feeding trends. HortScience 35(4):673-676.

Crane, M.B. 1937. Breeding immune rootstocks. Ann. Appl. Biol. 24:188-195.

Crassweller, R., R. McNew, A. Azarenko, B. Barritt, R. Belding, L. Berkett, S. Brown, J. Clemens, J. Cline, W. Cowgill, D. Ferree, E. Garcia, D. Greene, G. Greene, C. Hampson,I. Merwin, D. Miller, S. Miller, R. Moran, J. Obermiller, D. Rosenberger, C. Rom, T. Roper, J. Schupp, and E. Stover. 2005. Performance of apple cultivars in the 1995 NE-183 regional project planting: I. Growth and yield characteristics. J.Amer. Pomol. Soc. 59(1):18-27.

Cummins, J.N. and H.S. Aldwinckle. 1974. Breeding apple rootstocks. HortScience 9:367-372.

Cummins, J.N., P.L. Forsline, and J.D. Mackenzie. 1981. Woolly apple aphid colonization on Malus cultivars. J. Amer. Soc. Hort. Sci. 106(1):26-30.

Dean, R.W. and P.J. Chapman. 1973. Bionomics of the apple maggot in eastern New York. Search $3: 1-58$.

Downing, R.S. and T.K. Moilliet. 1967. Relative densities of predaceous and phytophagous mites on three varieties of apple trees. Can. Entomol. 99:738-741.

Ghate, A.V. and A.J. Howitt. 1965. Mite resistance to organophosphorous compounds and the response of apple varieties in Michigan. Mich. Agr. Expt. Sta. Quart. Bul. 47: 322-350.

Goonewardene,H.F. 1987.E11-24,E14-32, andE36-7 apple germplasm with multiple pest resistance. HortScience 22(6):1346-1348.

Goonewardene, H.F., W.F. Kwolek, R.E. Dolphin, and E.B. Williams. 1975. Evaluating resistance of apple fruits to four insect pests. HortScience 10(4):393-394.

Goonewardene, H.F., W.F. Kwolek, T.E. Mouzin, and E.B. Williams. 1979. A "no choice" study for evaluating resistance of apple fruits to four insect pests. HortScience 14(2):165-166.

Goonewardene, H.F., E.B. Williams, W.F. Kwolek, and L.D. McCabe. 1976. Resistance to European red mite, Panonychus ulmi (Koch), in apple. J. Amer. Soc. Hort. Sci. 101(5):532-537.

Greene, D., A. Azarenko, B. Barritt, B. Belding, L. Berkett, J.Cline, W.Cowgill, D. Ferree, E. Garcia, G. Greene, C. Hampson, R. McNew, I. Merwin, D. Miller, S. Miller, R. Moran, M. Parker, D. Rosenberger, C. Rom, T. Roper, J. Schupp, and E. Stover. 2004. Multidisciplinary evaluation of new apple cultivars: The NE-183 regional project. J. Amer. Pomol. Soc. 58(2):61-64.

Greene, D.W., R.A. Norton, C.R. Rom, R.L. Stebbins, and R.Way. 1997. The Brooks and Olmo register of fruit and nut varieties. 3rd ed. ASHS Press, Alex., Va.

Hogmire, H.W. (ed.). 1995. Mid-Atlantic orchard monitoring guide. NRAES-75. N.E. Reg. Agr. Eng. Serv., Ithaca, N.Y.

Hogmire, H., A. Biggs, and S. Miller. 2000. Call of the states-West Virginia. Proceedings 76th Cumberland-Shenandoah Fruit Workers Conference, Winchester, Va, 16-17 Nov.

Krawczyk, G. (ed.). 2004. Pennsylvania tree fruit production guide. College Agr. Sci. Publ. CAT AGRS-45.

Mackenzie, J.D. and J.N. Cummins. 1982. Differ- entiation of Malus clones into resistance classes by their effects on the biology of Eriosoma lanigerum Hausmn. J. Amer. Soc.Hort. Sci. 107(5):737-740.

Messina, F.J. and V.P. Jones. 1990. Relationship between fruit phenology and infestation by the apple maggot(Diptera: Tephritidae) in Utah. Ann. Entomol. Soc. Amer. 83:742-752.

Miller, S., R. McNew, R. Belding, L. Berkett, S. Brown, J. Clements, J. Cline, W. Cowgill, R. Crassweller, E. Garcia, D. Greene, G. Greene, C. Hampson, I. Merwin, R. Moran, T. Roper, J. Schupp, and E. Stover. 2004. Performance of apple cultivars in the 1995 NE-183 regional project planting: II. fruit quality characteristics. J. Amer. Pomol. Soc. 58:65-77.

Murphy, B.C., L.T. Wilson, and R.V. Dowell. 1991. Quantifying apple maggot (Diptera: Tephritidae) preference for apples to optimize distribution of traps among trees. Environ. Entomol. 20:981-987.

Pfeiffer, D.G. (ed.). 1996. Virginia and West Virginia spray bulletin for commercial tree fruit growers. Va. Coop. Ext. Serv. Publ. 456-419.

Rull, J. and R.J. Prokopy. 2004. Host-finding and ovipositional-boring responses of apple maggot (Diptera:Tephritidae) to differentapple genotypes. Environ. Entomol. 33(6):1695-1702.

SAS Institute. 2001. Version 8.2. SAS Inst. Inc., Cary, N.C.

Straub, D. 2003. Susceptibility of new apple cultivars to various arthropod pests. New York Fruit Quarterly 11(2):25-28.

Underhill, G.W. and J.A. Cox. 1938. Studies on the resistance of apple to the woolly apple aphid [Eriosoma lanigerum (Hausm.)]. J. Econ. Entomol. 31:622-625. 